\title{
THE ADOPTION OF E-GOVERNMENT IN THE TAX ADMINISTRATION: A SCOPING REVIEW
}

\author{
Nugroho Dian Respati
}

Directorate General of Taxation, Lubuklinggau. Email: nugroho.respati@pajak.go.id

\section{ABSTRACT}

With the spread of information, technology and the Internet, we have found that the tax administration is moving towards online or digital services. The study aims to identify what has worked in the adoption of e-government in tax services. The key aspects include the design of e-government in tax procedures, acceptance and usability factors, impacts, and challenges in the implementation. A scoping review was designed to map the existing evidence on the application of information and technology system in delivering tax services, or known as e-government. Key search terms were developed and mapped. Selected databases and key journals were used in this scoping review. Using the criteria that were determined, we identified 79 articles that most closely demonstrated the purpose of this study. However, we only reported the detailed of the findings from ten included articles. The identified studies reflected the majority of articles investigated the reasons behind the success or failure of e-government projects in the tax administration. This review concludes that in an environment in which the government faced many challenges with the limited resources, e-government adoption in tax administration offers the potential benefit to strengthen the government finances. A greater understanding of the purpose, adoption \& acceptance factors, the impact and challenges in the application of e-government projects in tax services is a priority for research, policy and practice.

Keywords: demographic transition, state budget, tax revenue.

\section{ABSTRAK}

Dengan berkembangnya penyebaran informasi, teknologi dan internet, kami menemukan bahwa administrasi perpajakan sedang bergerak ke arah layanan online atau digital. Penelitian ini bertujuan mengidentifikasi apa yang yang telah dilakukan dalam adopsi e-government di layanan pajak. Aspek-aspek kunci yang dikaji termasuk desain e-government dalam prosedur perpajakan, faktor diterimanya dan kegunaan, dampak, serta tantangan implementasi e-government. Metode scoping review dirancang untuk memetakan bukti-bukti yang telah ada berkaitan dengan 
layanan perpajakan melalui penerapan sistem informasi dan teknologi, atau dikenal sebagai e-government. Kata kunci utama dikembangkan dan dipetakan. Database dan jurnal utama dipilih dalam scoping review ini. Dengan menggunakan kriteria yang ditentukan, kami mengidentifikasi 79 artikel yang paling mendekati tujuan penelitian ini. Namun, kami hanya melaporkan rincian temuan dari sepuluh artikel. Studi yang diidentifikasi mencerminkan mayoritas artikel menyelidiki alasan di balik keberhasilan atau kegagalan proyek e-government dalam administrasi pajak. Tinjauan ini menyimpulkan bahwa dalam lingkungan yang pemerintah menghadapi banyak tantangan dengan sumber daya yang terbatas, adopsi e-government dalam administrasi perpajakan menawarkan manfaat potensial untuk memperkuat keuangan pemerintah. Pemahaman yang lebih besar tentang tujuan, faktor adopsi \& penerimaan, dampak dan tantangan dalam penerapan proyek e-government dalam layanan pajak adalah prioritas untuk penelitian, kebijakan, dan praktik dalam topik ini.

Kata kunci: transisi demografis, anggaran negara, pendapatan pajak.

\section{INTRODUCTION}

The government worldwide are facing several challenges: demographic changes, economic globalisation, reduced expenditure, labour market changes, differentiation and personalisation processes (Fuertes \& McQuaid, 2013). We cannot neglect that all countries also concern about the ways to increase their revenues, especially from taxes. As a result, it is important to note that governments should have ability in both raising and spending fiscal resources effectively and efficiently (Kochanova et al., 2016). The literature tells us that high costs and burdens of tax compliance, because of bulky regulations and some malpractices by tax inspectors, may prevent investment, drive tax evasion and ultimately undermine the economic growth (Hindriks et al., 1999; Coolidge, 2012; Kochanova et al., 2016). During the last decades, there have been trends that the public sector adopted e-government in delivering their services, including in tax administration. Many policy makers, academicians and international institutions acknowledge e-government as a means to modernise the public areas (Chaouali et al., 2016; Bhuiyan, 2011; Mishra \& Mishra, 2012). There are many definitions of e-government concept that are proposed by various authors and agencies (Moatshe, 2014). In this essay, we use a definition of e-government services from World Bank (2015) that refers to

"the use by government agencies of information technologies (such as Wide Area Networks, the Internet, and mobile computing) that have the ability to transform relations with citizens, businesses, and other arms of government. 
These technologies can serve a variety of different ends: better delivery of government services to citizens, improved interactions with business and industry, citizen empowerment through access to information, or more efficient government management. The resulting benefits can be less corruption, increased transparency, greater convenience, revenue growth, and/or cost reductions."

Therefore, the note here is on the implementation of information technologies in enhancing citizengovernment interactions, cost-cutting and generation of income and transparency. From a citizen and taxpayers' perspective, e-government services can save effort and time, enable accessibility 24 hours a day and seven days a week, and strengthens the relationship between the government and the user, and increases the citizen's participation (Chaouali et al., 2016).

The purpose of the scoping review is to provide a summary of the current research literature in adopting e-government in tax administration. It is designed to look at what are the purposes of the adoption and how its objectives can be achieved. The key aspects include the design of e-government in tax procedures, the pre-requisites of implementation, the acceptance and usability factors, benefits and outcomes, and challenges in the implementation.

Although scoping studies are a relatively new approach in searching literature (Davis et al., 2009), this method has been gaining popularity and widespread as a means to summarise research especially in the fields related to health and education (O'Flaherty \& Phillips, 2015). Scoping reviews differ from systematic reviews because the latter usually attempt to answer specific questions, with defined methodologies to examine articles' quality of included citations (Brien et al., 2010). In contrast, scoping reviews are usually conducted to incorporating literature, gathering a broad range of research methodologies and nature of studies in a particular topic, without assessing its quality (O'Flaherty \& Phillips, 2015). Scoping studies generate a profile of the current literature in particular field, producing a rich literature's database that can provide a foundation for further clarifying and following detailed reviews (Levac et al., 2010).

In current literature, the author has found some scoping review and systematic review that discussed the topic of e-government. Holeman et al. (2016) analysed the use and effects of digital technology in the context of health care in low and middle-income countries. Andersen et al. (2010) reviewed the impacts of e-government on four dimensions within the public sector: capabilities, value distribution, interactions, and orientations. Allan et al. (2006) synthesise the literature to focus on the term and concept of eGovernment. Mishra and Mishra (2012) examined the research to highlight the different domains of e-government: 
challenges, implementation, and success factors. However, there has been no scoping or systematic studies on e-government in tax administration. Therefore, this scoping review aims to fill this lack of scoping studies and also to identify which areas in the adoption of e-government in the tax sector that need further research. This is parallel with the reasons identified by Arksey and O'Malley (2005). They found that there are four potential reasons why researchers should employ a scoping study. These are to assess the extent and nature of research activity; to determine whether a systematic review is valuable;

\section{RESEARCH METHODOLOGY}

The study is following the five-stage framework of scoping review provided by Arksey \& O'Malley (2005). This guidance employs a rigorous process of transparency, allowing replication of the search strategy and enhancing the reliability of the study findings. The five stages of Arksey and O'Malley's guidelines which involve: (1) identifying the research questions, (2) identifying relevant studies, (3) study selection, (4) charting the data, and (5) collating, summarising and reporting the results are adopted in this review of the e-government literature. This study aims to synthesise existing research for policy - makers and to provide a rigorous assessment of the evidence base. Therefore, the target audience of this research is government staff, non - profit organisations and to summarise and disseminate research findings; and to know the research gaps within the current literature (Arksey \& O'Malley, 2005, p. 21).

This paper itself is organised as follows. The first section presents the introduction and background of the study. It is followed by the discussion of the research methodology. The next section reports the findings from the scoping review processes, which is followed with the discussion. Finally, the last section describes the impact of the study on e-government research and practice, the limitations and the conclusions of the study.

international organisations that focus on increasing tax administration performance and tax revenue. We aim to present the data from this scoping review in a way that is accessible to policy-makers.

\subsection{Identifying the Research Questions}

The first stage is determining what the research questions are. This research focuses on the exploration of key aspects of the e-government adoption in the tax administration. It proposes the following research questions to guide the search:

1) What are the purposes of adopting e-government in the tax administration?

2) What are the types of technologies used and in which tax procedures is e-government implemented? 
3) What is known about the adoption and acceptance factors of e-government?

4) What are the impacts arising from e-government services in tax sector?

5) What is known about the challenges and barriers in the implementation of e-government in tax administration?

\subsection{Identifying Relevant Studies}

In the second phase, key words and search terms were formulated to seize the potential literature relevant to e-government in tax administration. The search strings for this research were formulated by combining different terms of e-government and tax administration as presented in Table 1. The table shows that the e-government terms were searched based on the spelling of e-government, the synonym of e-government and some special terms of e-government in the tax administration. Regarding tax administration terms, this research gathers terms that are used in many countries for their tax organisations. Many countries put the word "tax" in their tax departments, but it is found that some countries use the term "revenue" in the tax institutions, such as the United Kingdom (HM Revenue and Customs) and the United States (Internal Revenue Services/IRS).

\begin{tabular}{|c|c|}
\hline Item & Terms \\
\hline \multicolumn{2}{|l|}{ E-government terms } \\
\hline Spelling of "e-government" & $\begin{array}{l}\text { "eGovernment" or "egovernment" or "EGovernment" or } \\
\text { "Egovernment" or "EGOV" or "egov" or "electronic } \\
\text { government" or "e-Government" or "E-government" or "E- } \\
\text { GOV" or "e-Gov" or "e-gov" }\end{array}$ \\
\hline Synonym of "e-government" & "digital government" \\
\hline $\begin{array}{l}\text { Specific terms of "e- } \\
\text { government" in tax } \\
\text { administration }\end{array}$ & $\begin{array}{l}\text { "eTax" or "eTaxation" or "e-Tax" or "electronic Tax" or "mTax" } \\
\text { or "mTaxation" or "mobile tax" or "mobile taxation" or } \\
\text { "online Tax" or "online Taxation" or "online-Tax" }\end{array}$ \\
\hline \multicolumn{2}{|l|}{ Tax administration terms } \\
\hline Tax administration & $\begin{array}{l}\text { "Tax" or "Tax administration" or "Tax organization" or } \\
\text { "Department of Tax" or "Tax Office" or "Tax Agencies" or Tax } \\
\text { services }\end{array}$ \\
\hline $\begin{array}{l}\text { Tax organization in some } \\
\text { countries using terms } \\
\text { "Revenue" for their institutions }\end{array}$ & $\begin{array}{l}\text { "Revenue" or "Revenue administration" or "Revenue } \\
\text { organization" or "Revenue Department" or "Revenue Office" } \\
\text { or "Revenue Agencies" }\end{array}$ \\
\hline \multicolumn{2}{|c|}{ Key terms used } \\
\hline \multicolumn{2}{|c|}{$\begin{array}{l}\text { ("eGovernment" OR "egov" OR "electronic government" OR \{e-Government\} OR }\{\text {-Gov\} OR } \\
\text { "Digital Government" OR "eTax*" OR \{e-Tax*\} OR "electronic tax*" OR "mTax*" OR "mobile Tax*" } \\
\left.\text { OR "onlineTax*" OR "online Tax*" OR \{online-Tax }{ }^{*}\right\} \text { ) AND ("Tax" or "Revenue") }\end{array}$} \\
\hline
\end{tabular}


In this scoping review, the references search was done through six electronic databases and hand-searching. The six databases from which the search was performed are as follows:

1) Web of Science (previously known as Web of Knowledge: http://apps.webofknowledge.com)

2) Science Direct (http://sciencedirect.com)

3) Scopus (http://www.scopus.com)

4) Proquest (http://www.proquest.com)

5) IEEE Explore (http://ieeexplore.ieee.org)

Besides looking up the references in the six electronic databases, this scoping review searched the references by hand-searching. It was conducted by perusing the two key journals, i.e., The Electronic Journal of e-Government (EJEG/http://ejeg.com) and Journal of
e-Government Studies and Best Practice (JEGSBP/http://ibimapublishing.com).

\subsection{Study Selection}

The third stage in this scoping review was selecting the studies that addressed the formulated research questions. This step requires a mechanism to assist the researcher to eliminate the citations that do not match the purposes (Arksey \& O'Malley, 2005). Comprehensive gathering of literature evidence is an objective of this study; however, the practicalities of cost and time constraints should be considered (Kenny et al., 2013; O'Flaherty \& Phillips, 2015). Therefore, this study developed the inclusion and exclusion criteria to ensure getting the best fit for our review objectives. A full list of inclusion and exclusion criteria is outlined in Table 2 .

Table 2. Inclusion and Exclusion Criteria

Source: Author's analysis

\begin{tabular}{|c|c|c|}
\hline Criterion & Inclusion & Exclusion \\
\hline \multicolumn{3}{|l|}{ General Criteria } \\
\hline Time period & 2000 to 2017 & before 2000 \\
\hline Language & English & Non-English studies \\
\hline Type of article & $\begin{array}{l}\text { Journal, } \quad \text { Conference } \\
\text { papers, book sections }\end{array}$ & $\begin{array}{l}\text { Newspaper, editorial or overview of } \\
\text { conference proceedings }\end{array}$ \\
\hline Geographical & All countries & - \\
\hline \multicolumn{3}{|l|}{ Topic of Studies } \\
\hline Study focus & $\begin{array}{l}\text { Evaluate e-govemment in } \\
\text { tax administration }\end{array}$ & $\begin{array}{l}\text { - Adoption e-government not in tax sector } \\
\text { - Does not evaluate e-government in tax } \\
\text { administration } \\
\text { - Designing the e-government but no } \\
\text { evaluation }\end{array}$ \\
\hline Context of study & $\begin{array}{l}\text { in national or country } \\
\text { context }\end{array}$ & $\begin{array}{l}\text { in not national country context (macro } \\
\text { level, region or local government area) }\end{array}$ \\
\hline Status of study & Published or finished study & On-going study \\
\hline \multicolumn{3}{|l|}{ Study design } \\
\hline Type of study & Empirical study & $\begin{array}{l}\text { Macro level study } \\
\text { Theoretical study } \\
\text { Not empirical study }\end{array}$ \\
\hline Research methods & $\begin{array}{l}\text { All types of methods but it } \\
\text { should be described } \\
\text { clearly. }\end{array}$ & $\begin{array}{l}\text { Not clearly in describing the research } \\
\text { methodology such as not mentioning data } \\
\text { collection or no description of population } \\
\text { studied provided (for quantitative studies). }\end{array}$ \\
\hline \multicolumn{3}{|c|}{ Accessibility and Availability } \\
\hline Citations access & $\begin{array}{l}\text { Full text is available and } \\
\text { accessible }\end{array}$ & Full text is not available or accessible \\
\hline
\end{tabular}


The articles included in this technical review cover high-quality quantitative and qualitative evidence on what has worked in the adoption of e-government in the tax administration in all countries. Based on this concept, articles that did not evaluate the e-government implementation were excluded. Furthermore, the research limited the inclusion criteria by the time the study was conducted and the language used. It is found that the term "e-government" had been used since the 1990s to show a different vision of information technology especially in the context of public sector reform (Gupta \& Panzardi, 2008). Therefore, an evaluation of the e-government after a decade of implementation was deemed appropriate. The selection process only included articles that were published in 2000 until the time of the scoping review conducted (May 18th, 2017), collecting only studies written in or translated into English. As this research focusses on tax administration at the national level, the selection also excluded studies evaluating e-government in non-tax services and its adoption in local or municipal tax services.

After composing the search terms as well as the inclusion and exclusion criteria, the study searched the citations in six databases plus EJEG and JEGSBP as the key journals. In doing this, adjusted Boolean operators for each database based on the key terms were composed to narrow down the results. In addition, to reduce the number of irrelevant hits, the search was limited only into the titles, abstracts, and keywords of the articles. Apart from the six databases, the references search was also conducted manually in the EJEG and JEGSBP journals to find the articles missing from these databases.

Using the developed search descriptors, 871 articles were identified through six databases and 19 additional articles were obtained from the two key journals. After excluding the duplicates items, the titles and abstracts of the articles were screened through. The result revealed a significant number of irrelevant studies that did not match the inclusion criteria. Most of these articles did not address the adoption of e-government or only addressed the adoption of e-government without focusing on tax administration. Through a process of elimination, driven by inclusion/exclusion criteria, 183 studies were identified as potentially relevant.

In the next step, full-text versions of the articles were obtained and reviewed. Although many previous scoping studies (Mitton et al., 2009; Kenny et al., 2013; O'Flaherty \& Phillips, 2015) employed two or more people to examine the eligibility of the articles in meeting the criteria, the full-text review in this study was performed single-handedly. In ensuring the quality of the included articles, the assessment was repeated three times. Finally, 79 studies were identified as being relevant to the research topic. To attain comprehensive selection of the articles, the process followed the Preferred Reporting of Items for Systematic Reviews and Meta-Analyses (PRISMA) Statement (Moher et al., 2010). Fig. 1 below illustrates how this scoping study selected the citations. 
Figure 1. Literature Search Results and Study Selection

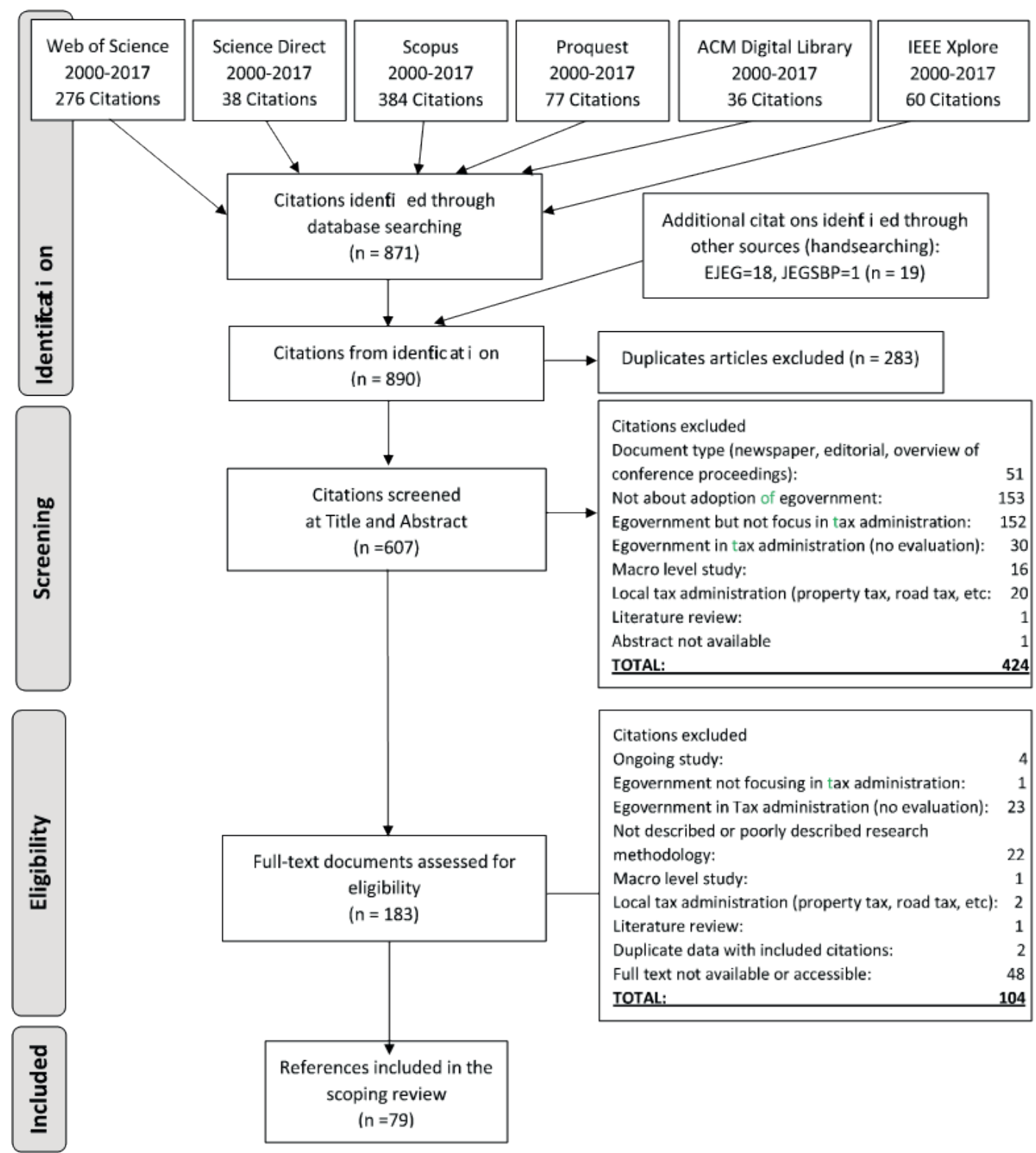

As shown in Figure 1, a number of studies addressing e-government had to be excluded during the research selection's process, for example, two ongoing studies (Connolly \& Bannister, 2007, 2010), were ruled out. Since the focus of the coping review is looking the implementation of e-government in tax procedures, several studies discussing only the design of e-government in tax administration without evaluation, such as the research written by Terblanche (2014) and Huang and Yang (2012), were not included. 
In addition, articles which discuss the topic in macro-levels (Economides \& Terzis, 2008) and address local tax administration (Canares, 2016; Gonzalez et al., 2007) were also filtered out. Due to limitation to access full-text articles from publishers, for example the International Publisher of Information Science and Technology Research (http://igi-global.com), some research (Chen \& Huang, 2009; Carter et al., 2016) could not be assessed for eligibility.

\subsection{Data Charting and Collation}

The fourth stage is mapping the selected articles, in accordance with Arksey and O'Malley's (2005) framework. Although this scoping review selected 79 citations in the final inclusion, it only charted 10 out of 79 articles in this stage because of time and human resource constraints. However, the scoping review has ensured that the chosen articles represent the variety aspects of the total, especially regarding countries, topics and research methodologies.

The 79 included studies represent 27 countries for the locations of the studies, with the top four countries being Taiwan (11 articles), Malaysia (10), USA (9) and Thailand (8). By continents, Asia has the highest numbers of literature (47 articles), followed by America and Europe with 13 and 12 articles, respectively. Africa and Australia, with 5 and 3 studies, in that order, rank lowest. It is worth nothing that there is an article studying two countries (Chang Lee, et al., 2008). The detail of the included studies is provided in Table 3.

Table 3. The key features of the 10 included studies

Source: Study's results

\begin{tabular}{|c|c|c|c|c|}
\hline $\begin{array}{c}\text { (Study Number) } \\
\text { Author } \\
\text { details/Year/ } \\
\text { Documents' } \\
\text { type }\end{array}$ & $\begin{array}{c}\text { Location } \\
\text { (Country \& } \\
\text { Region \& Tax } \\
\text { Institution Name) }\end{array}$ & E-government description & Methodology / Participant & Outcomes of the study \\
\hline $\begin{array}{c}\text { (1) } \\
\text { Alam, Campbell } \\
\text { \& Lucas (2011) } \\
\text { Conference } \\
\text { Paper }\end{array}$ & $\begin{array}{c}\text { Australia } \\
\text { Australia } \\
\text { Australian } \\
\text { Taxation Office } \\
\text { (ATO) }\end{array}$ & $\begin{array}{l}\text { Type of e-government: } \\
\text { e-Tax Facebook page (social } \\
\text { media). } \\
\text { Year of adoption: } 2008 \text {. } \\
\text { Purpose \& target: } \\
\text { a. Enhancing Tax office's ability } \\
\text { to communicate and interact } \\
\text { to taxpayers } \\
\text { b. Enhancing business and } \\
\text { community perception to the } \\
\text { Tax Office. }\end{array}$ & $\begin{array}{l}\text { Single Case Study using } \\
\text { both qualitative and } \\
\text { quantitative methods. } \\
\text { Data taken from comments } \\
\text { on Facebook page. }\end{array}$ & $\begin{array}{l}\text { - Findings: } \\
\text { e-Tax Facebook page is difficult } \\
\text { to find, no links to the ATO web } \\
\text { or } \\
\text { e-Tax software, is only used for } \\
\text { one-way communication, many } \\
\text { negative comments without } \\
\text { response. } \\
\text { - Suggestion: } \\
\text { Change the style of } \\
\text { communication, make the page } \\
\text { easier to find, state the page for } \\
\text { official. }\end{array}$ \\
\hline $\begin{array}{c}\text { (2) } \\
\begin{array}{l}\text { Pippin \& Tosun } \\
(2014)\end{array} \\
\text { Journal Article }\end{array}$ & $\begin{array}{c}\text { USA } \\
\text { North America } \\
\text { Internal Revenue } \\
\text { Service (IRS) }\end{array}$ & $\begin{array}{l}\text { Type of e-govemment: } \\
\text { e-filing: Tax return reporting. } \\
\text { Year of adoption: 1980s (piloting) } \\
1998 \text { (started promoting). } \\
\text { Purpose \& target: } \\
\text { to improve public perception of } \\
\text { the IRS, which had suffered from } \\
\text { various corruption scandals, as } \\
\text { well as to increase its overall } \\
\text { efficiency. }\end{array}$ & $\begin{array}{l}\text { Quantitative method. } \\
\text { Secondary data taken: } \\
\text { - E-filing data from IRS } \\
\text { Statistics. } \\
\text { - Demographic and other } \\
\text { data from the Bureau of } \\
\text { Economic Analysis (BEA), } \\
\text { the Bureau of Labor } \\
\text { Statistics (BLS) and the } \\
\text { census bureau. }\end{array}$ & $\begin{array}{l}\text { - Findings } \\
\text { Demographic, socio-economic, } \\
\text { and geographic factors affect } \\
\text { the e-filing adoption. } \\
\text { Environmental factors such as } \\
\text { gender, population, race, etc. } \\
\text { have effects on the use of e- } \\
\text { filing. }\end{array}$ \\
\hline
\end{tabular}




\begin{tabular}{|c|c|c|c|c|}
\hline $\begin{array}{c}\text { (Study Number) } \\
\text { Author } \\
\text { details/Yearl } \\
\text { Documents' } \\
\text { type }\end{array}$ & $\begin{array}{c}\text { Location } \\
\text { (Country \& } \\
\text { Region \& Tax } \\
\text { Institution Name) }\end{array}$ & E-government description & Methodology / Participant & Outcomes of the study \\
\hline $\begin{array}{c}\text { (3) } \\
\text { Floropoulos, } \\
\text { Spathis, } \\
\text { Halvatzis \& } \\
\text { Tsipouridou } \\
\text { (2010) } \\
\text { Journal Article }\end{array}$ & $\begin{array}{c}\text { Greece } \\
\text { Southern Europe } \\
\text { Ministry of } \\
\text { Finance }\end{array}$ & $\begin{array}{l}\text { Type of e-govemment: } \\
\text { Greek Taxation Information } \\
\text { System (TAXIS): Integration of } \\
\text { eighteen tax subsystems } \\
\text { including registration, VAT, } \\
\text { Income Tax, Audit, e-Filing and } \\
\text { many others. } \\
\text { Year of adoption: mid-1990s } \\
\text { Purpose \& target: } \\
\text { a.more productive and efficient } \\
\text { services to taxpayers: } \\
\text { b. improvement of the citizens' } \\
\text { trust to the taxation system } \\
\text { justice, etc. }\end{array}$ & $\begin{array}{l}\text { Quantitative Survey } \\
\text { The samples were } 340 \\
\text { taxation employees of the } \\
\text { departments of Public } \\
\text { Economic Agencies (PEAs) } \\
\text { throughout Greece. }\end{array}$ & $\begin{array}{l}\text { - Findings } \\
\text { The study measures the } \\
\text { success of TAXIS from the } \\
\text { perspective of expert } \\
\text { employees through five } \\
\text { variables: information quality, } \\
\text { service quality, perceived } \\
\text { usefulness, system quality and } \\
\text { user satisfaction. The first three } \\
\text { variables affected the success } \\
\text { of TAXIS with service quality as } \\
\text { the strongest variable. }\end{array}$ \\
\hline $\begin{array}{c}\text { (4) } \\
\text { Ali, Shifa, } \\
\text { Shimeles, \& } \\
\text { Woldeyes (2015) } \\
\text { Journal Article }\end{array}$ & $\begin{array}{c}\text { Ethiopia } \\
\text { East Africa } \\
\text { Ethiopian } \\
\text { Revenue and } \\
\text { Customs Authority } \\
\text { (ERCA) }\end{array}$ & $\begin{array}{l}\text { Type of e-govemment: } \\
\text { electronic sales registry } \\
\text { machines (ERCA): VAT } \\
\text { reporting. } \\
\text { Year of adoption: } 2003 \\
\text { Purpose \& target: } \\
\text { a.to solve some issues: lack of } \\
\text { fiscal resources, low tax } \\
\text { revenue as share of GDP. } \\
\text { b.to monitor transactions easily. }\end{array}$ & $\begin{array}{l}\text { Quantitative method } \\
\text { (econometric analysis). } \\
\text { Data of tax payments and } \\
\text { electronic sales registry } \\
\text { machines (ESRM) use from } \\
\text { VAT-registered firms in } \\
\text { ERCA's database. }\end{array}$ & $\begin{array}{l}\text { - Challenges faced: } \\
\text { a. Machine cost is expensive. } \\
\text { b. Requires ERCA to handle } \\
\text { information system and } \\
\text { monitor the users compliance } \\
\text { etc. } \\
\text { - Benefits taken: } \\
\text { a. Increase tax payments. } \\
\text { b. Minimise tax evasion } \\
\text { c. increase tax compliance. }\end{array}$ \\
\hline $\begin{array}{c}\text { (5) } \\
\text { Barnes \& Vidgen } \\
\quad(2007) . \\
\text { Journal Article }\end{array}$ & $\begin{array}{c}\text { United Kingdom } \\
\text { Northern Europe } \\
\text { UK Inland } \\
\text { Revenue }\end{array}$ & $\begin{array}{l}\text { Type of e-government: } \\
\text { Tax website: submission of self- } \\
\text { assessed tax returns and } \\
\text { interactive communication for tax } \\
\text { policy. } \\
\text { Year of adoption: } 1999 \text { (starting } \\
\text { the online submission of tax } \\
\text { return). } \\
\text { Purpose \& target: } \\
\text { a.Part of the project to provide all } \\
\text { services electronically }\end{array}$ & $\begin{array}{l}\text { Mixed: Quantitative and } \\
\text { Qualitative Method. } \\
\text { Collecting data using } \\
\text { Internet-based } \\
\text { questionnaires. } \\
\text { Collected } 420 \text { usable } \\
\text { responses from the Tax } \\
\text { website users or taxpayers. }\end{array}$ & $\begin{array}{l}\text { Findings } \\
\text { - The study measures the } \\
\text { experience of users in using the } \\
\text { online taxation systems. The } \\
\text { factors used are usability, } \\
\text { design, information, and trust. } \\
\text { - Both quantitative and qualitative } \\
\text { data can be used for measuring } \\
\text { the perceptions of users to the } \\
\text { systems identifying the areas of } \\
\text { difficulty in the system }\end{array}$ \\
\hline $\begin{array}{c}\text { (6) } \\
\text { Bhuasiri, Lee \& } \\
\text { Ciganek (2016) } \\
\text { Journal Article }\end{array}$ & $\begin{array}{c}\text { Thailand } \\
\text { Southeast Asia } \\
\text { The Thai Revenue } \\
\text { Department }\end{array}$ & $\begin{array}{l}\text { Type of e-government: } \\
\text { E-tax filing and payment. } \\
\text { Year of adoption: } 2002 \\
\text { Purpose \& target: } \\
\text { a.enhancing the efficiency of tax } \\
\text { collection; } \\
\text { b.increasing alternatives for tax } \\
\text { filing and payment; etc }\end{array}$ & $\begin{array}{l}\text { Quantitative Method. } \\
\text { Collecting data through } \\
\text { questionnaire. Before the } \\
\text { survey, pilot study was } \\
\text { conducted. Questionnaire } \\
\text { was distributed via email. }\end{array}$ & $\begin{array}{l}\text { - Findings } \\
\text { Factors that influence users to } \\
\text { use e-tax filing and payment: } \\
\text { a. performance expectancy; } \\
\text { b. facilitating conditions; } \\
\text { c. social influence; and } \\
\text { d. perceived credibility. }\end{array}$ \\
\hline $\begin{array}{c}\text { (7) } \\
\text { Wang \& Doong } \\
(2010) \\
\text { Journal Article }\end{array}$ & $\begin{array}{c}\text { Taiwan } \\
\text { East Asia } \\
\text { National Tax } \\
\text { Administration } \\
\text { (NTA) }\end{array}$ & $\begin{array}{l}\text { Type of e-government: } \\
\text { Tax e-filing system (TEFS): Tax } \\
\text { return reporting } \\
\text { Year of adoption: } 1998 \\
\text { Purpose \& target: } \\
\text { Enhancing the efficiency and } \\
\text { precision of the tax filing system. }\end{array}$ & $\begin{array}{l}\text { Quantitative Method by } \\
\text { collecting secondary data. } \\
\text { Data of the annual numbers } \\
\text { of TEFS adopters during } \\
\text { the period from } 1998 \text { to } \\
2005 \text { were obtained from } \\
\text { the Department of Treasury } \\
\text { in Taiwan. }\end{array}$ & $\begin{array}{l}\text { Findings } \\
\text { - The study analyses government } \\
\text { promotion efforts as the factor } \\
\text { that influences the adoption of } \\
\text { e-filing by the citizens. } \\
\text { - TEFS is proposed to be } \\
\text { determined by (1) government } \\
\text { promotion efforts, which are } \\
\text { outside the citizens' social } \\
\text { network and (2) word-of-mouth, } \\
\text { which is within the citizens' } \\
\text { social network. }\end{array}$ \\
\hline $\begin{array}{c}\text { (8) } \\
\text { Ghazali, } \\
\text { Mustapha \& } \\
\text { Mozie } \\
(2014) \\
\text { Conference } \\
\text { Paper }\end{array}$ & $\begin{array}{c}\text { Malaysia } \\
\text { Southeast Asia } \\
\\
\text { Lembaga Hasil } \\
\text { Dalam Negeri } \\
\text { (LHDN) / Inland } \\
\text { Revenue Board } \\
\text { (IRB) }\end{array}$ & $\begin{array}{l}\text { Type of e-government: } \\
\text { E-filing: Tax returns reporting. } \\
\text { Year of adoption: } 2003 \\
\text { Purpose \& target: } \\
\text { Not stated }\end{array}$ & $\begin{array}{l}\text { Quantitative Method. } \\
\text { Collecting data through } \\
\text { questionnaire. } \\
\text { The samples are } 196 \\
\text { Assistant Directors of } \\
\text { government agencies (civil } \\
\text { servants) }\end{array}$ & $\begin{array}{l}\text { Findings } \\
\text { - The study looks at factors that } \\
\text { could be considered in } \\
\text { predicting people's intention. } \\
\text { - Factors that were analysed are } \\
\text { subjective norm and perceived } \\
\text { behavioural control. }\end{array}$ \\
\hline
\end{tabular}




\begin{tabular}{|c|c|c|c|c|}
\hline $\begin{array}{c}\text { (Study Number) } \\
\text { Author } \\
\text { details/Yearl } \\
\text { Documents' } \\
\text { type }\end{array}$ & $\begin{array}{c}\text { Location } \\
\text { (Country \& } \\
\text { Region \& Tax } \\
\text { Institution Name) }\end{array}$ & E-government description & Methodology / Participant & Outcomes of the study \\
\hline $\begin{array}{l}\text { (9) } \\
\text { Ojha, Sahu, \& } \\
\text { Gupta (2009) } \\
\text { Journal Article }\end{array}$ & $\begin{array}{c}\text { India } \\
\text { South Asia } \\
\text { Indian Income Tax } \\
\text { Department }\end{array}$ & $\begin{array}{l}\text { Type of e-government: } \\
\text { e-filing: tax returns reporting. } \\
\text { Year of adoption: } 2004 \\
\text { Purpose \& target: } \\
\text { to enable taxpayers in meeting } \\
\text { their normal tax obligations in a } \\
\text { convenient and timely manner } \\
\text { without visiting Tax offices }\end{array}$ & $\begin{array}{l}\text { Quantitative Method. } \\
\text { Collecting data using } \\
\text { Survey. } \\
\text { The participants were } \\
\text { students who studied } \\
\text { engineering and } \\
\text { management. Two weeks } \\
\text { before the survey, the } \\
\text { participants received a } \\
\text { lecture on how to fill in the } \\
\text { income tax return form } \\
\text { through } \\
\text { e-filing. }\end{array}$ & $\begin{array}{l}\text { Findings } \\
\text { - The study investigates the } \\
\text { behaviour intention to use } \\
\text { e-filing among young people. } \\
\text { - Factors influenced the intention } \\
\text { are: perceived ease-of-use, } \\
\text { personal innovativeness in } \\
\text { information, technology, relative } \\
\text { advantage (RA), performance of } \\
\text { e-filing service, and compatibility } \\
\text { (COMP). }\end{array}$ \\
\hline $\begin{array}{c}(10) \\
\text { Kawaguchi, H. } \\
(2009) \\
\text { Conference } \\
\text { Paper }\end{array}$ & $\begin{array}{c}\text { Japan } \\
\text { East Asia } \\
\text { National Tax } \\
\text { Agency (NTA) }\end{array}$ & $\begin{array}{l}\text { Type of e-government: } \\
\text { e-tax: Tax return reporting. } \\
\text { Year of adoption: not stated. } \\
\text { Purpose \& target: } \\
\text { Eight objectives were stated } \\
\text { such as: } \\
\text { a. To shorten the processing time } \\
\text { of reporting with refunds } \\
\text { utilizing e-Tax. } \\
\text { b. To implement a } 24 \text {-hour e-Tax } \\
\text { desk during the period of } \\
\text { income tax returns. } \\
\text { c. To simplify the work and etc. }\end{array}$ & $\begin{array}{l}\text { Quantitative Method. } \\
\text { Collecting data through } \\
\text { Online survey. } \\
\text { The participants were } \\
\text { administrative } \\
\text { scriveners who are obliged } \\
\text { to file income tax returns. } \\
101 \text { responses were } \\
\text { received. }\end{array}$ & $\begin{array}{l}\text { Findings } \\
\text { - The study analyses the effect of } \\
\text { incentives in the e-government } \\
\text { implementation. } \\
\text { - Incentives are effective for e- } \\
\text { Tax utilisation and promotion. }\end{array}$ \\
\hline
\end{tabular}

\subsection{Summarising and Reporting Findings}

The final stage of Arksey and O'Malley's (2005) framework provides a summary and reports the findings from included studies. This scoping review

\section{FINDINGS}

This paper has charted the ten articles in Table 3. The summary of these articles, pertaining to the initial research questions, are presented below.

\subsection{What are the purposes of adopting e-government in the tax administration?}

The purposes of the e-government adoption from the ten only selected ten articles from all included articles. Consequently, the reporting part focuses on the ten articles in attempting to answer the research questions and achieving the purpose of this study. The findings are reported in the following section.

articles have been detailed in Table 3. It is important to note that the tax authorities determined the objectives before the implementation of e-government. These objectives are classified into four groups as follows:

a. Improving service delivery

The application of e-government in tax services was expected to provide better services owing to shortened time, improved efficiency and 
convenience in completing transactions $(2,3,5-7,9,10)$. It was also targeted to reduce the costs of tax compliance (6).

b. Improving civil service performances E-government can could be used to enhance the performance of tax officers. It was targeted to increase the ability of tax staff to interact, communicate with taxpayers as well as monitor transactions

Furthermore, it improved the efficiency of tax inspectors and eliminated the errors by automating the tax procedures $(2,3,6,7,10)$ as well as increased the speed of workflow and data gathering $(5,6,10)$.

c. Improving government finances

E-government could reduce the cost of tax transactions for the government (6), increase tax revenue and minimise the tax evasion $(3,4)$. Moreover, it might have helped in better planning and controlling of taxation policies (3).

d. Increasing transparency and reducing corruption

The last purpose identified in this scoping review was that e-government could improve the trust and public perception of the citizens to the tax office and eliminate corruption $(1,2,3)$.

\subsection{What are the types of technologies used and in which tax procedures is e-government implemented?}

E-government has been adopted in a variety of tax procedures in the ten countries included in the scoping review. Nearly all tax agencies built the systems for income tax return reporting or known as e-filing (2,7-10). Some countries integrated the e-filing with a system for tax payments (6), or with website (5). Another created a system for VAT reporting (4). Interestingly, in building the systems these countries integrated many subsystems (3) or made use of social media such as "Facebook" for tax communication channel (1).

\subsection{What is known about the adoption and acceptance factors of e-government?}

For this section, factors that influence the adoption and acceptance of e-government in the Tax Administration were reviewed. The main aim was to provide a better understanding of the characteristics and dimensions that can lead to the success and sustainability of the e-government implementation. Six topic categories are developed to broadly represent the factors investigated in the 10 articles are as follows:

a. Demographic, socio-economic and geographic factors

The demographic, socio-economic and geographic variables were indicated to have an influence on the adoption of e-filing in the United States (2). Demographic features such as ethnicity, gender and age combined with socio-economic measures such as average income, unemployment rates and living region's type (urban or rural) were tested to verify the factors that affected to the acceptance of e-filing. 
By using regression analysis, it was found that e-filing rates were lower in rural areas with low population size, smaller share of females, higher proportion of Hispanics and Asians and greater share of the elderly populations. However, it is surprising that there was no significant relationship between educational attainment and e-government adoption (2).

b. Individual characteristics

The majority of the articles investigated the effect of individual features on e-government adoption by following some previous theories and model. These models were Delone and McLean and Seddon's instrument (3), E-qual instrument (5), UTAUT model (6), Theory of Reasoned Action (TRA) and Theory of Planned Behavior (TPB) (8), and the combination of several models (9). According to these models, the effects of individual characteristics on person's intentions and behaviours to use e-government were thought to be mediated by their attitudes and beliefs. It was found that the perceived usefulness of income tax e-filing was significant in predicting the young professionals' intention to adopt them (9). Similarly, the perceived ease of the use on adoption or usability was the most important factor for both group of people who had experience in using the tax website in the United Kingdom and who had not (5). This was also the first reason of utilising e-Tax in Japan (10). It was also found that the perceived ease of use variable had an influence on the user satisfaction of the e-government users (3). The perceived ease of use on the adoption itself was determined by the service quality variable (3). The service quality also had a significant effect on user satisfaction when using the TAXIS system in Greece (3) and using UK Tax website (5).

Besides the perceived ease of use, this scoping review also identified many others antecedents of people's intention in adopting e-government in tax services. These factors are perceived behavioural control (8), performance expectancy, effort expectancy, perceived credibility, social influence (6), relative advantage, and the performance of service (9). Surprisingly, subjective norms (8) and perceived risk (6) were not significant in influencing the citizens' intention in adopting e-government in tax services.

c. Improving government finances The scoping review observed that some studies investigated the effect of information and technology design characteristics on individuals' acceptance and the use of e-government applications in tax services. System quality and information quality factors were found to significantly influenced individuals' adoption of e-government services $(3,5)$. Other factors in IT features - personal innovativeness in IT and compatibility (9), design (5) - were significantly 
having an association with the citizens' intention to use e-government in tax services.

d. Promotion

One of the ten articles focussed on the promotion aspect of e-government in Taiwan taxation services (7). The Taiwan study developed three models of e-government promotion - external, internal and mixed influences model - to find which channel has successfully spread information about e-government in tax services. Although the government has spent a larger budget for buying advertisements in promoting e-government, this external strategy only played a limited role in influencing the adoption of e-government services by citizens. The study suggested that the external model should be combined with the internal influence (word-of-mouth) strategy to be effective. Therefore, the mixed influence model was considered as the best fit for spreading the information of e-government and ultimately increasing the adoption of e-government by citizens (7).

e. Incentive effects

The last factor identified was the influence of stimulus. One study conducted a survey to investigate the effect of incentives in motivating citizens to use e-Tax in Japan. The study's findings indicated that 5,000-yen tax credit was an effective incentive to promote e-Tax adoption and utilisation (10).

\subsection{What are impacts arising from e-government services in tax sector?}

There was only one article that scrutinised the impact of e-government adoption. It attempted to analyse the impact of Electronic Sales Registry Machine (ESRM) on VAT e-government services in Ethiopia by giving empirical evidence (4). The research concluded that applying information and technology in the tax services has potential impacts on strengthening the state fiscal capacity. By analysing the pattern of VATs payments since the beginning of the ESRM implementation, it was discovered that tax payments by firms had increased after the use of ESRM. The average of VAT payments is had increased by about 17\% after ESRM use. The results also suggested that ESRM use could minimise the intention of companies to do tax evasion (4).

\subsection{What is known about the challenges and barriers in the implementation of e-government in tax administration?}

Whereas e-government in tax services evidently had good impacts on the government finance as mentioned earlier, it came with many challenges. The first problem is related to the cost of e-government implementation. For example, implementing ESRM for VAT reporting and payments in Ethiopia required around 250 to 650 USD per machine installed in one company. As a result, the utilisation of the ESRM was 
carried out in several rounds (4). Lack of confidence in skills, resources and knowledge owned by taxpayers $(6,8)$ and by those who lived in the rural areas $(2,8)$ was another barrier in adopting e-government. Preparing organisational capacity of the tax institutions for e-government services is another task to respond to.

\section{DISCUSSIONS}

This section summarises and conveys the findings to provide a panoramic overview of what have been known about the adoption of e-government in tax administration and to identify prominent gaps within the literature.

\subsection{What are the purposes of adopting e-government in the tax administration?}

The results of the scoping review show that there are several objectives stated by the tax authorities when adopting information and technology in their tax services. Most e-government projects in tax administrations aim to improve the services and civil servants' performance. Other targets are related to the government finance and transparency improvement. This scoping review identifies that the objectives determined were related to the background and condition that occurred in the tax administration before the adoption of e-government. For example, the adoption of
For example, ERCA, the tax authority of Ethiopia, was required to handle and monitor the operational of ESRM. Expanding the use of ESRM has raised the need to increase the number of staff to run the system and the user compliance during the implementation of e-government services (4).

e-government in Internal Revenue Service (IRS) in the United States was initiated to improve public perception of the IRS which had suffered from various corruption scandals (2).

Although the purposes of the application of e-government are varied, there has been limited research that evaluated the achievement of its purposes. This review shows that most studies focussed on the factors that influenced the adoption of e-government. Only one out of the ten articles included analyses the impact of e-government on tax revenues (4). The literature needs more empirical evidence to see how far the objectives of the e-government application in the tax services have been achieved.

\subsection{What are the types of technologies used and in which tax procedures is the e-government implemented?}

Most of the studies included in this scoping review evaluated e-filing and VAT systems in the tax administration. Some studies revealed that 
several tax agencies developed an integrated taxation system and used social media for tax dissemination and consultation. For example, one study examines the implementation of TAXIS which comprises eighteen subsystems in Greek tax administration. This could be improved, nonetheless, by exploring and acquiring more detailed knowledge of each subsystem. E-filing and VAT have become prominent issues in implementing e-government in tax services, as these systems are directly associated with almost all taxpayers. However, we cannot neglect the fact that other tax procedures are also critical for the tax institution. For instance, the role of e-audit or office automation in tax administration could be an interesting topic of e-government study.

\subsection{What is known about the adoption and acceptance factors of e-government?}

The scoping study has reviewed and found several key antecedents of e-government adoption and acceptance factors in the tax administration. However, much work needs to be done in investigating these factors. The variables of demographic, geographic and individual factors have seemingly been explored in more detail, while the topics of technology effect, mandatory or voluntary setting, promotion and incentives require more investigation in the future research. Furthermore, this scoping review identifies severalother factors which have not been covered in the included ten articles.
The management support, back-office and leadership discussed in previous studies (Chan, Pan, \& Tan, 2003; Homburg \& Bekkers, 2002; Ke \& Wei, 2004; Kifle \& Cheng, 2009; and Furuholt \& Wahid, 2008) are believed to have influenced e-government adoptions outside the tax administration. Furuholt and Wahid (2008) confirmed that strong leadership was required in the e-government adoption, especially to manage the limited resources available and to monitor the progress during the implementation.

Interestingly, the majority of the articles discussing the adoption and acceptance factors employed quantitative method through surveys or questionnaires $(3,6,8,9)$ and secondary data (2). There was only one study that used the mixed method of quantitative and qualitative data in analysing the factors of e-government adoption by using survey in collecting the data (5). The scoping review recognised that the respondents of the previous studies varied, as they came from different backgrounds. Some studies engaged tax agencies employees (3), civil servants (8), students (9), and taxpayers $(5,6)$ as participants of the surveys. Although the quantitative studies had a variety of participants, the future research could benefit from adopting qualitative methods such as interviews, focus group discussions, and otherdata collection approaches. The qualitative methods can be used for a deeper understanding of the complex behaviours, systems and cultures (Ritchie and Spencer, 1994). 
Other factors that might be needed in investigating the e-government application in tax administration are organisational characteristics. There is a debate whether or not red tape (excessive bureaucratic regulation) has an influence on the e-government adoption. Moon and Bretschneider (2002) have found that there is an interdependent relationship between bureaucracy and IT innovations, while Welch and Pandey (2007) argued that the intranet technology has no significant association with the red tape issue although it was found that red tape had a negative association with the information quality.

In sum, the importance of demographic, geographical, and individual characteristics of e-government adoption in tax services appears to have been clearly established. However, carrying out a larger number of the future studies related to the effect of promotion, voluntary or mandatory setting and incentive would probably gain much explanatory power. Furthermore, the future studies also need to explore the influence of management support and leadership as well as organisational features on the e-government adoption in tax institutions. This study also recommends more research making use of in qualitative methods to identify the factors of e-government adoption and acceptance in the tax administration.

\subsection{What are impacts arising from e-government services in tax sector?}

The management support, back-office and leadership discussed in previous studies (Chan, Pan, \& Tan, 2003; Homburg \& Bekkers, 2002; Ke \& Wei, 2004; Kifle \& Cheng, 2009; and Furuholt \& Wahid, 2008) are believed to have influenced e-government adoptions outside the tax administration. Furuholt and Wahid (2008) confirmed that strong leadership was required in the e-government adoption, especially to manage the limited resources available and to monitor the progress during the implementation.

Interestingly, the majority of the articles discussing the adoption and acceptance factors employed quantitative method through surveys or questionnaires $(3,6,8,9)$ and secondary data (2). There was only one study that used the mixed method of quantitative and qualitative data in analysing the factors of e-government adoption by using survey in collecting the data (5). The scoping review recognised that the respondents of the previous studies varied, as they came from different backgrounds. Some studies engaged tax agencies employees (3), civil servants (8), students (9), and taxpayers $(5,6)$ as participants of the surveys. Although the quantitative studies had a variety of participants, the future research could benefit from adopting qualitative methods such as interviews, focus group discussions, and otherdata collection approaches. The qualitative methods can be used for a deeper understanding of the complex behaviours, systems and cultures (Ritchie and Spencer, 1994). 


\section{IMPLICATIONS FOR RESEARCH AND PRACTICE}

It is evident from the current review that many aspects and dimensions determine the successful of e-government in tax services. Demographic, socio-economic, geographical, individual characteristics, promotion and incentives are examples of the factors already investigated from the ten articles included in the scoping study. Future research should consider to elaborate these factors further, including to observe other factors that might have influence on e-government adoption. The roles of organisation characteristics, management support and leadership in tax administration when adopting e-government could be an interesting topic for future studies and it would enrich the knowledge of e-government. Moreover, this study suggests the need for more research utilising interviews, focussed group discussions or other qualitative approaches to scrutinise the reasons behind the success or failure of e-government projects in the tax administration.

The scoping review has identified some gaps in the literature that need to be addressed for effective implementation of e-government in delivering tax services. These include the under-exploration of promotion and incentives effects of e-government, the impacts of e-government, the barriers in e-government projects as well as the variety of tax policy and services that utilise information and technology features.

\section{LIMITATIONS}

This scoping review has several limitations. Firstly, there was some limitation to access the journals that would have otherwise been relevant to the topic. Secondly, due to time and human resource constraints, this review could only include a limited number of electronic databases in searching the literature. Others electronic databases and journals about e-government, which have not been included in this study, might contain articles that could better answer the research questions. Thirdly, although the articles have been scanned and screened through using the developed criteria, they are subject to errors as the activities were done single-handedly. Finally, it is acknowledged that discussing all aspects of the e-government adoption in tax administration is a challenging task; however, this review has tried to include all significant findings in the ten included articles.

\section{CONCLUSIONS}

The purpose of the scoping study was to describe the current literature from both electronic databases and key journals that evaluated the adoption e-government in the tax administration. The research investigated what has worked in the e-government of tax services. It is evident that there are many aspects, factors, or antecedents that determine the success of e-government. The factors of demographic and individual characteristics were deeply investigated in the current literature; 
however, we cannot neglect the effect of promotion and incentive on the e-government applications. Policy makers, especially those in tax authorities who plan or are still in the process of implementing e-government in tax services should understand this issue to prevent the failure of the projects. The investigation of the reasons behind the success and failure of e-government projects has become an interesting domain of study; therefore, it is not surprising that the scoping review found the majority of the included articles took this issue as their topics. Furthermore, this study emphasises the lack of research in analysing the factors of e-government adoption and acceptance that adopts qualitative approaches. The current studies mostly used surveys or questionnaires in their quantitative studies, so the future research is expected to fill the gap by taking the interviews or focus group discussions as their approaches for collecting the data.

This study finds that the information and technology features that are adopted in tax administration varied. Thus, tax administration has become one of the institutions in the public sectors that leads the e-government adoption. The use of Facebook, e-filing, VAT reporting, and integrated taxation systems have shown the usefulness of the technology, especially when we look at the impact of e-government on government finance. The potential benefit of e-government in increasing tax payments and reducing tax evasion cases should be used as the motivation for governments around the world to prioritise the implementation of e-government in the tax sector. As a result, these financial benefits can strengthen the state's fiscal capacity and capability, especially at the time when the government are in the pressure of raising and spending fiscal resources effectively and efficiently.

The scoping review points out some topics that are still underexplored in the current literature. The challenges in the adoption of e-government in tax administration need to be addressed in future studies. Furthermore, the issue of how the aspects of management support, leadership and organisational characteristics can influence the adoption of e-government in tax administration, as evidenced in the studies of e-government in other sectors, shows that these variables are significantly associated with the success of e-government projects.

All in all, perhaps, this scoping study can give a distinctive contribution in identifying potential gaps and further development of e-government research as well as in investigating what has been examined in existing literature on this particular subject. 


\section{REFERENCES}

[1] Alam, S. L., Campbell, J., \& Lucas, R. (2011). Using Social Media in government: the Australian taxation office e-tax Facebook page. In Dependable, Autonomic and Secure Computing (DASC), 2011 IEEE Ninth International Conference on (pp. 1002-1009). IEEE.

[2] Ali, M., Shifa, A. B., Shimeles, A., \& Woldeyes, F. (2015). Building fiscal capacity in developing countries: Evidence on the role of information technology. CMI (Chr. Michelsen Institute), Bergen, Norway.

[3] Allan, J. D., Rambajun, N., Sood, S. P., Mbarika, V., Agrawal, R., \& Saquib, Z. (2006, November). The egovernment concept: A systematic review of research and practitioner literature. In Innovations in Information Technology. (pp. 1-5). . IEEE.

[4] Andersen, K. N., Henriksen, H. Z., Medaglia, R., Danziger, J. N., Sannarnes, K, M., \& Enemærke, M. (2010). Fads and Facts of E-Government: A Review of Impacts of Egovernment (2003-2009). International Journal of Public Administration, 33(11), 564-579.

[5] Arksey, H., \& O'Malley, L. (2005). Scoping studies: towards a methodological framework. International Journal of Social Research Methodology, 8(1), pp.19-32.

[6] Barnes, S. J., \& Vidgen, R. (2007). Interactive e-government: Evaluating the web site of the UK Inland Revenue. International Journal of Electronic Government Research, 3(1), 19.

[7] Bhuasiri, W., Zo, H., Lee, H., \& Ciganek, A. P. (2016). User Acceptance of e-government Services: Examining an e-tax Filing and Payment System in Thailand. Information Technology for Development, 22(4), 672-695.

[8] Bhuiyan, S. (2011). Modernizing Bangladesh public administration through e-governance: Benefits and challenges. Government Information Quarterly, Volume 28, Issue 1, Pages 54-65.

[9] Brien, S., Lorenzetti, D., Lewis, S., Kennedy, J., \& Ghali, W. (2010). Overview of a formal scoping review on health system report cards. Implementation Science, 5(1).
[10] Canares, M. P. (2016). Creating the Enabling Environment for More Transparent and Better-resourced Local Governments: A Case of E-taxation in the Philippines. Information Technology for Development, 22(sup1), 121-138.

Carter, L., McFadden-Wade, G., \& Wells, J.

[11] (2016). Exploring the impact of organizational citizenship behavior on perceptions of e-filing success. International Journal of Public Administration in the Digital Age (IJPADA), 3(1), 43-52.

[12] Chan, C., Pan, S., \& Tan, C. W. (2003). Managing stakeholder relationships in an e-government project. AMCIS 2003 Proceedings, 98.

Chang Lee, K., Kirlidog, M., Lee, S., \& Gun Lim, G. (2008). User evaluations of tax filing

[13] web sites: A comparative study of South Korea and Turkey. Online Information Review, 32(6), 842-859.

Chaouali, W., Yahia, I., Charfeddine, L., \& Triki, A. (2016). Understanding citizens' adoption of e-filing in developing countries: An empirical investigation. The Journal of High

[14] Technology Management Research, 27(2), 161-176.

Chen, C., \& Huang, E. (2009). A study on taxpayers' willingness to use self-service

[15] technology-based online government services. Journal of Electronic Commerce in Organizations (JECO), 7(2), 44-66.

Connolly, R., \& Bannister. (2007). Trust and

[16] the taxman: a study of the Irish revenue's website service quality. Electronic Journal of e-Government, 5(2), 127-134.

Connolly, R., \& Bannister, F. (2010, May). Government eTax systems: Factors influencing citizen adoption. In Research

[17] Challenges in Information Science (RCIS), 2010 Fourth International Conference on (pp. pp. 79-84). IEEE.

Coolidge, J. (2012). Findings of tax compliance cost surveys in developing

[18] countries. e-Journal of Tax Research, 10 (2), 250-279. 
[19] Davis, K., Drey, N., \& Gould, D. (2009). What are scoping studies?: A review of the nursing literature. International Journal of Nursing Studies, 46, 1386-1400.

[20] Economides, A. A., \& Terzis, V. (2008). Evaluating tax sites: an evaluation framework and its application. Electronic Government, an International Journal, 5(3), 321-344.

[21] Ernst \& Young. (2016). Tax administration is going digital: Understanding the challenges and opportunities. Retrieved from Ernst \& Young:

http://www.ey.com/Publication/vwLUAssets/ EY-tax-administration-is-going-digital/\$FILE /EY-tax-administration-is-going-digital.pdf Floropoulos, J., Spathis, C., Halvatzis, D., \& Tsipouridou, M. (2010). Measuring the success of the Greek taxation information system. International Journal of Information Management, 30(1), 47-56.

[22] Fuertes, V., \& McQuaid, R. (2013). The Work Programme: a new public governance policy or a continuation of new public management? Working paper series FVeP 20 ISSN: 2240-3272.

[23] Furuholt, B., \& Wahid, F. (2008). E-government Challenges and the Role of Political Leadership in Indonesia: the Case of Sragen. In Hawaii International Conference on System Sciences, Proceedings of the 41st Annual (pp. 411-411). IEEE.

[24] Ghazali, N., Mustapha, R. M., \& Mozie, N. M. (2014). The adoption factors of using e-Government services:(Study case in Malaysia). In Technology, Informatics, Management, Engineering, and Environment (TIME-E), 2014 2nd International Conference. IEEE.

[25] Gonzalez, R., Gasco, J., \& Llopis, J. (2007). E-government success: some principles from a Spanish case study. Industrial Management \& Data Systems, 107(6), 845-861.

[26] Gupta, T., \& Panzardi, R. (2008). The Role of E-Government in Building Democratic Governance (with a Special Focus on Latin America). Washington, DC: The World Bank. Hindriks, J., Keen, M., \& Muthoo, A. (1999). Corruption, extortion and evasion. Journal of Public Economics, 74(3), 395-430.
[27] Holeman, I., Cookson, T., \& Pagliari, C. (2016). Digital technology for health sector governance in low and middle income countries: a scoping review. Journal of Global Health, 6(2).

[28] Homburg, V., \& Bekkers, V. J. (2002). The back-office of e-government (managing information domains as political economies. In System Sciences, 2002. HICSS. Proceedings of the 35th Annual Hawaii International Conference on (pp. 1666-1674). IEEEE.

[29] Huang, W., \& Yang, L. (2012, March). E-Tax Network System Design Based on IP. In Computer Science and Electronics Engineering (ICCSEE), 2012 International Conference on (pp. (Vol. 1, pp. 212-216)). IEEE.

[30] Kawaguchi, H. (2009). Incentive effects in the decision to utilize e-tax in Japan. In Proceedings of the 8tWSEAS International Conference on E-Activities and information security and privacy (pp. pp. 136-141). World Scientific and Engineering Academy and Society (WSEAS).

[31] Ke, W., \& Wei, K. K. (2004). Understanding E-Government Development: A Case Study of Singapore E-Government. AMCIS 2004 Proceedings, 86.

[32] Kenny, A., Hyett, N., Sawtell, J., Dickson-Swift, V., Farmer, J., \& O'Meara, P. (2013). Community participation in rural health: A scoping review. Health Services Research, 13(64), 1-8.

[33] Kifle, H., \& Cheng, P. L. (2009). E-government Implementation and Leadership: the Brunei Case Study. Academic Conferences.

Kochanova, A., Hasnain, Z., \& Larson, B. R. (2016). Does e-government improve government capacity ? evidence from tax administration and public procurement. Washington, D.C. : World Bank Group. Available at:

http://documents.worldbank.org/curated/e n/334481468193734893/Does-e-governme nt-improve-government-capacity-evidencefrom-tax-administration-and-public-procure ment 
[34] Levac, D., Colquhoun, H., \& O'Brien, K. (2010). Scoping studies: advancing the methodology. Implementation Science, 5(1). Mishra, A., \& Mishra, D. (2012). E-government: exploring the different dimensions of challenges, implementation, and success factors. ACM SIGMIS Database, 42(4), 23-37.

[35] Mitton, C., Smith, N., Peacock, S., Evoy, B., \& Abelson, J. (2009). Public participation in health care priority setting: a scoping review. Health policy, 91(3), 219-228.

[36] Moatshe, R. M. (2014). E-government implementation and adoption: the case study of Botswana Government (Doctoral Dissertation). University of Derby. Retrieved from http://hdl.handle.net/10545/337831

[37] Moher, D., Liberati, A., Tetzlaff, J., \& Altman, D. (2010). Preferred reporting items for systematic reviews and meta-analyses: The PRISMA statement. International Journal of Surgery, 8(5), pp.336-341.

[38] Moon, M. J., \& Bretschneiber, S. (2002). Does the perception of red tape constrain IT innovativeness in organizations? Unexpected results from a simultaneous equation model and implications. Journal of Public Administration Research and Theory, 12(2), 273.

[39] O'Flaherty, J., \& Phillips, C. (2015). The use of flipped classrooms in higher education: A scoping review. The Internet and Higher Education, 25, 85-95.

[40] Ojha, A., Sahu, G. P., \& Gupta, M. P. (2009). Antecedents of paperless income tax filing by young professionals in India: An exploratory study. Transforming Government: People, Process and Policy, 3(1), 65-90.

[41] Pippin, S. E., \& Tosun, M. S. (2014). Electronic Tax Filing in the United States: An Analysis of Possible Success factors. Electronic Journal of e-Government, Volume 12 Issue 12014 , (pp22-38). Retrieved from www.ejeg.com

[42] Ritchie, J., \& Spencer, L. (1994). Chapter 9: Qualitative data analysis for applied policy research. In R. Burgess, \& A. Bryman, Analyzing qualitative data 1st ed. (pp. 173-194). London: Routledge.
[43] Terblanche, J. T. (2014). Design of an e-registration prototype using $\mathrm{HCl}$ principles: with specific reference to tax registration. Conference paper at Proceedings of the 24th International Business Information Management Association Conference-Crafting. Wang, H. C., \& Doong, H. S. (2010). Does

[44] government effort or citizen word-of-mouth determine e-Government service diffusion? Behaviour \& Information Technology, 29(4), 415-422.

[45] Welch, E. W., \& Pandey, S. K. (2007). E-government and bureaucracy: Toward a better understanding of intranet implementation and its effect on red tape. Journal of Public Administration Research and Theory, 17(3), 379-404.

[46] World Bank. (2015). E- Governments. Retrieved from World Bank: http://www.worldbank.org/en/topic/ict/brief le-governmen 